Research article

\title{
Antibodies to cyclic citrullinated protein and erythrocyte sedimentation rate predict hand bone loss in patients with rheumatoid arthritis of short duration: a longitudinal study
}

\author{
Pernille Bøyesen 1, Mari Hoff², Sigrid Ødegård'1, Glenn Haugeberg"2,3, Silje W Syversen ${ }^{1}$,
}

Per I Gaarder ${ }^{4}$, Cecilie Okkenhaug ${ }^{5}$ and Tore K Kvien ${ }^{1}$

\author{
1Department Rheumatology, Diakonhjemmet Hospital, Diakonveien 12, N-0370 Oslo, Norway \\ 2Department of Rheumatology, St Olav's Hospital, University Hospital of Trondheim, Olav Kyrres gt 17, N-7006 Trondheim, Norway \\ ${ }^{3}$ Department of Rheumatology, Sørlandet Hospital, Service box 416, N-4604 Kristiansand S., Norway \\ ${ }^{4}$ Department of Immunology and Transfusion Medicine, University Hospital Ullevål, Kirkeveien 166, N-0459 Oslo, Norway \\ ${ }^{5}$ Department of Medical Biochemistry, Diakonhjemmet Hospital, Diakonveien 12, N-0370 Oslo, Norway \\ Corresponding author: Pernille Bøyesen, pernilleboyesen@gmail.com
}

Received: 2 Feb 2009 Revisions requested: 10 Mar 2009 Revisions received: 11 May 2009 Accepted: 1 Jul 2009 Published: 1 Jul 2009

Arthritis Research \& Therapy 2009, 11:R103 (doi:10.1186/ar2749)

This article is online at: http://arthritis-research.com/content/11/4/R103

(C) 2009 Bøyesen et al.; licensee BioMed Central Ltd.

This is an open access article distributed under the terms of the Creative Commons Attribution License (http://creativecommons.org/licenses/by/2.0), which permits unrestricted use, distribution, and reproduction in any medium, provided the original work is properly cited.

\begin{abstract}
Introduction Radiographic progression in rheumatoid arthritis (RA) has in several studies been shown to be predicted by serological markers widely used in daily clinical practice. The objective of this longitudinal study was to examine if these serological markers also predict hand bone mineral density (BMD) loss in patients with RA of short disease duration.

Methods 163 patients with RA of short disease duration (2.4 years) were included and followed longitudinally. Antibodies to cyclic citrullinated protein (anti-CCP), rheumatoid factor (RF), erythrocyte sedimentation rate (ESR), and C-reactive protein (CRP) were analysed from baseline blood-samples. Hand BMD was measured by digital X-ray radiogrammetry (DXR) based on hand and wrist radiographs obtained at baseline and 1, 2 and 5year follow-up.

Results During the study period, DXR-BMD decreased by median (inter quartile range) $1.7 \%$ ( 4.1 to 0.4 ), $2.8 \%$ (5.3 to 0.9 ) and $5.6 \%$ (11.7 to 2.3 ) after 1,2 and 5 years, respectively. Elevated baseline anti-CCP, RF, ESR and CRP levels were in univariate linear regression analyses consistently associated with DXR-BMD change at all time-points. Anti-CCP and ESR were independently associated with hand DXR-BMD in multivariate linear regression analyses. Elevated anti-CCP levels were consistent and independent predictors of loss in cortical hand bone during the study period, with the odds ratios $(95 \%$ confidence interval) 2.2 (1.0 to 4.5), 2.6 (1.1 to 6.2) and 4.9 (1.4 to 16.7) for the 1, 2, and 5-year follow-up periods, respectively. Conclusions Anti-CCP and ESR were found to be independent predictors of early localised BMD loss. This finding adds to the understanding of anti-CCP and ESR as important predictors of bone involvement in RA.
\end{abstract}

\section{Introduction}

Rheumatoid arthritis (RA) is a chronic inflammatory disease characterised by synovitis and bone destruction. The inflammation in RA causes a shift in the bone metabolism towards increased osteoclast-mediated bone turn-over [1,2]. This dysregulation causes reduced bone mass, which is known to be an early feature in RA patients, visualised as juxta-articular bone demineralisation on radiographs [3]. Quantification of this localised bone loss has been proposed as an outcome measure in early RA [4]. Measurements of localised bone involvement in RA can be performed by digital $\mathrm{X}$-ray radiogrammetry (DXR), which gives an estimate of cortical hand bone mineral density (BMD) $[5,6]$.

Anti-CCP: antibodies to cyclic citrullinated peptide; BMD: bone mineral density; CRP: C-reactive protein; DMARD: disease-modifying antirheumatic drugs; DXR: digital X-ray radiogrammetry; DXR-BMD: hand bone mineral density estimated by digital X-ray radiogrammetry; ELISA: enzyme-linked immunosorbent assay; ESR: erythrocyte sedimentation rate; HAQ: health assessment questionnaire; Ig: immunoglobulin; IL1: interleukin 1; LSC: least significant change; RA: rheumatoid arthritis; RANKL: receptor activator of nuclear factor-kappaB ligand; RF: rheumatoid arthritis; TNF $\alpha$ : tumour necrosis factor $\alpha$. 
Early intervention with disease-modifying antirheumatic drugs (DMARDs), which inhibit joint damage, is accepted as a cornerstone in the treatment strategy of RA $[7,8]$. Further, the disease course of RA is heterogeneous and about one-third of RA patients do not experience joint damage $[9,10]$. Thus, the identification of patients prone to bone involvement is important at an early stage of the disease in order to individually tailor the RA treatment and optimise disease outcome [1]. DXR has been shown to measure bone loss in early arthritides and RA [11]. As a measurement of early bone destruction in RA, DXR-BMD has also been shown to predict subsequent radiographic damage [12]. Previous studies have shown that serological biomarkers can predict radiographic damage, a late measure of bone involvement in RA [13].

The objective of this study was to examine if serological markers widely used in daily clinical practice also can predict early involvement of bone measured by DXR in a longitudinal study of patients with RA of short disease duration.

\section{Materials and methods \\ Patients}

As part of the EURIDISS (European Research on Incapacitating Disease and Social Support) study, a Norwegian arm of the cohort was followed longitudinally. At inclusion in 1992, 238 patients aged from 20 to 70 years, with a clinical diagnosis of RA and disease duration of less than four years were included [14]. The patients were assessed at baseline with blood samples, medical history and health assessment questionnaire (HAQ). Conventional, bilateral hand and wrist radiographs were taken at baseline and one, two and five-year follow-up. This article focuses on 163 patients who had radiographs taken at baseline and after one, two or five years followup. Of the 163 patients in this study, 128 had X-rays at all four time points, 29 at three time points and six patients at two time points. The patients with and without hand X-rays had similar baseline characteristics (Table 1). Treatment was given according to clinical practice. The percentages of patients who were treated with DMARDs/prednisolone at baseline, one, two and five years were 53.8/26.3, 46.9/28.1, 50.6/29.4 and $54.9 / 37.5$, respectively. The included patients gave

Table 1

\begin{tabular}{|c|c|c|c|}
\hline & Included patients $n=163$ & Excluded patients $n=75$ & $P$ value \\
\hline \multicolumn{4}{|l|}{ Demographic variables } \\
\hline Female & 75.0 & 70.5 & 0.53 \\
\hline Age (years) & 53.0 (43.0 to 62.3$)$ & 57.0 (43.5 to 64.5$)$ & 0.23 \\
\hline Disease duration (years) & 2.4 (1.2 to 3.2$)$ & 2.5 (1.2 to 3.1$)$ & 0.95 \\
\hline $\mathrm{HAQ}$ & $0.9(0.4$ to 1.4$)$ & $1.0(0.4$ to 1.4$)$ & 0.60 \\
\hline \multicolumn{4}{|l|}{ Treatment } \\
\hline DMARD use & 53.8 & 48.7 & 0.49 \\
\hline Prednisolone use & 26.3 & 29.5 & 0.64 \\
\hline \multicolumn{4}{|l|}{ Serological biomarkers } \\
\hline $\mathrm{ESR}(\mathrm{mm} / \mathrm{h})$ & 20.0 (10.0 to 38.0$)$ & 24.0 (10.5 to 35.5$)$ & 0.65 \\
\hline $\mathrm{ESR}>20 \mathrm{~mm} / \mathrm{h}$ & 48.5 & 52.0 & 0.58 \\
\hline $\mathrm{CRP}(\mathrm{mg} / \mathrm{l})$ & $6.0(0.0$ to 15.0$)$ & $7.0(2.5$ to 14.5$)$ & 0.36 \\
\hline $\mathrm{CRP}>10 \mathrm{mg} / \mathrm{l}$ & 28.8 & 26.0 & 0.66 \\
\hline $\lg \mathrm{A} R F(\mathrm{U} / \mathrm{ml})$ & 13.0 (4.0 to 41.3$)$ & 17.5 (1.8 to 75.0$)$ & 0.56 \\
\hline IgA RF positive & 30.2 & 33.3 & 0.87 \\
\hline $\operatorname{lgM} \mathrm{RF}(\mathrm{U} / \mathrm{ml})$ & $21.0(5.0$ to 105.0$)$ & 26.5 (2.0 to 131.0$)$ & 0.66 \\
\hline IgM RF positive & 41.7 & 66.7 & 0.40 \\
\hline Anti-CCP (U/ml) & 67.0 (4.4 to 243.0$)$ & 56.0 (3.5 to 251.0 ) & 0.82 \\
\hline Anti-CCP positive & 60.4 & 66.7 & 0.76 \\
\hline
\end{tabular}

The values are given as median (inter quartile range) for continuous variables, percentage for counts.

Anti-CCP = antibodies to cyclic citrullinated peptide; $\mathrm{CRP}=\mathrm{C}$-reactive protein; DMARD = disease-modifying antirheumatic drugs; $\mathrm{ESR}=$ erythrocyte sedimentation rate; $\mathrm{HAQ}=$ health assessment questionnaire; $\mathrm{lg}=$ immunoglobulin; $\mathrm{RF}=$ rheumatoid arthritis. 
informed consent and the study was evaluated and approved by the regional ethics committee.

\section{Laboratory analyses}

Erythrocyte sedimentation rate (ESR) was measured by the Westergren method, ranging from 0 to $140 \mathrm{~mm} / \mathrm{h}$. C-reactive protein (CRP) was measured by phyCardioPhase hs CRP nephelometry (Dade Behring, Deerfield, Illinois, USA) with a lowest detectable limit of $0.15 \mathrm{mg} / \mathrm{l}$ [9]. Antibodies to cyclic citrullinated protein (anti-CCP) was analysed by a second generation ELISA (INOVA Diagnostics Inc, San Diego, CA, USA) with a range from 0 to $251 \mathrm{U} / \mathrm{ml}$. Values above $25 \mathrm{U} / \mathrm{ml}$ were considered positive. Immunoglobulin ( $\mathrm{lg}$ ) A and IgM rheumatoid factor (RF) were measured by in-house ELISA technique, ranging from 2 to $300 \mathrm{U} / \mathrm{ml}$ and with a positive cut-off at $25 \mathrm{U} /$ $\mathrm{ml}$ [9]. The laboratory analyses used in this study were performed on baseline samples and the measures of CRP, antiCCP and RF were performed in frozen sera.

\section{Bone mineral density measurement of the hands}

BMD was measured by DXR (Pronosco X-posure 2.0, Sectra, Linköping, Sweden) based on conventional hand radiographs from baseline, one, two and five-year follow-up visits. DXR is a computer version of the traditional radiogrammetry technique and the method has previously been described in detail [6]. The DXR software automatically recognises the regions of interest (metacarps two to four) and measures the cortical thickness, bone width, and bone porosity 118 times per $\mathrm{cm}$. The precision of the DXR-BMD measurements was calculated based on duplicate hand radiographs from 28 healthy individuals with repositioning of the hand between each measure. The coefficient of variation was found to be $0.28 \%$, and the least significant change (LSC) was $0.79 \%$ [12]. Mean values of both hands were applied to avoid bias regarding dominant and non-dominant hand and to achieve better precision [15].

\section{Statistical analyses}

The analyses were performed using SPSS 14 statistics package (SPSS, Chicago, IL, USA). The baseline characteristics had a skewed distribution and were analysed using non-parametric methods. Independent groups were compared using Mann-Whitney $U$ test for continuous variables and chi-squared tests for dichotomous variables. DXR-BMD change was calculated as the percentage difference between the follow-up value and the baseline value. The individual zero to one, one to two and two to five years changes in DXR-BMD were illustrated by cumulative probability plots. DXR-BMD change was also depicted in probability plots stratified for anti-CCP more than $25 \mathrm{U} / \mathrm{ml}$ and $25 \mathrm{U} / \mathrm{ml}$ or less [16]. The distributions of the soluble biomarkers were skewed (independent variables), and were therefore for further analyses dichotomised according to the clinical cut-offs with elevated levels as follows: ESR above $20 \mathrm{~mm} / \mathrm{h}$, CRP above $10 \mathrm{mg} / \mathrm{l}$, IgA RF above $25 \mathrm{U} / \mathrm{ml}$, IgM RF above $25 \mathrm{U} / \mathrm{ml}$ and anti-CCP above $25 \mathrm{U} / \mathrm{ml}$.
The associations between the change in DXR-BMD and the baseline, dichotomised soluble biomarkers were explored by linear regression analyses. First, univariate linear regression analyses were performed with one, two and five-year change in BMD as dependent variables and the dichotomised soluble biomarkers as independent variables. Further, the independent variables with a $P \leq 0.25$ were included in multivariate linear analyses. The final multivariate models with only statistically significant variables were obtained by stepwise exclusion of the least significant variable from the models and corrected for age and sex.

Prediction of loss in cortical hand bone was further explored by logistic regression analyses. Loss in cortical hand bone was defined as a negative change in DXR-BMD exceeding the LSC. First, univariate logistic regression analyses were performed with one, two and five-year cortical hand bone loss as the dependent variable and the baseline, dichotomised serological biomarkers as independent variables. Secondly, the independent variables with $P \leq 0.25$ were included in multivariate logistic regression analyses. By stepwise exclusion of the least significant covariate, final models with only statistically significant variables were obtained and corrected for age and sex.

All tests were two-sided and $P \leq 0.05$ were considered to be statistically significant. Standard diagnostic tests of model assumptions and residuals were routinely performed. Residuals exceeding three standard deviations were checked for data errors.

\section{Results \\ Baseline demographics and soluble biomarkers}

Baseline demographics for included and excluded patients were similar and are summarised in Table 1.

\section{Bone mineral density}

DXR-BMD measurements from each examination time point and DXR-BMD change are presented in Table 2. DXR-BMD decreased significantly between all time points during the follow-up period $(P<0.05)$. Median (inter quartile range) DXRBMD loss between one and two years, and two and five years were $-1.46 \%$ (-1.88 to -1.04$)$ and $-3.81 \%$ (-4.68 to -2.95 ; Figure 1a). Younger women ( $\leq 50$ years) had a trend towards larger DXR-BMD loss than older women ( $>50$ years). Median one, two and five-year DXR-BMD change in younger women were $-2.32 \%,-3.39 \%$ and $-7.45 \%$ and in older women $1.15 \%,-1.73 \%$ and $-3.88 \%$, respectively. However, this trend was the same for the men included in the study (data not shown). DMARD/prednisolone-treated patients had significantly larger one, two and five-year DXR-BMD percentage loss than patients not treated with DMARD/prednisolone; 2.0/-2. 2 vs. $-1.1 /-1.3,-3.4 /-4.1$ vs. $-1.5 /-1.5$ and $-7.7 /-7.8$ vs. 3.3/-3.9, respectively. A loss in cortical hand bone exceeding the LSC was observed in $66.7 \%, 77.3 \%$ and $89.1 \%$ of the 
Figure 1

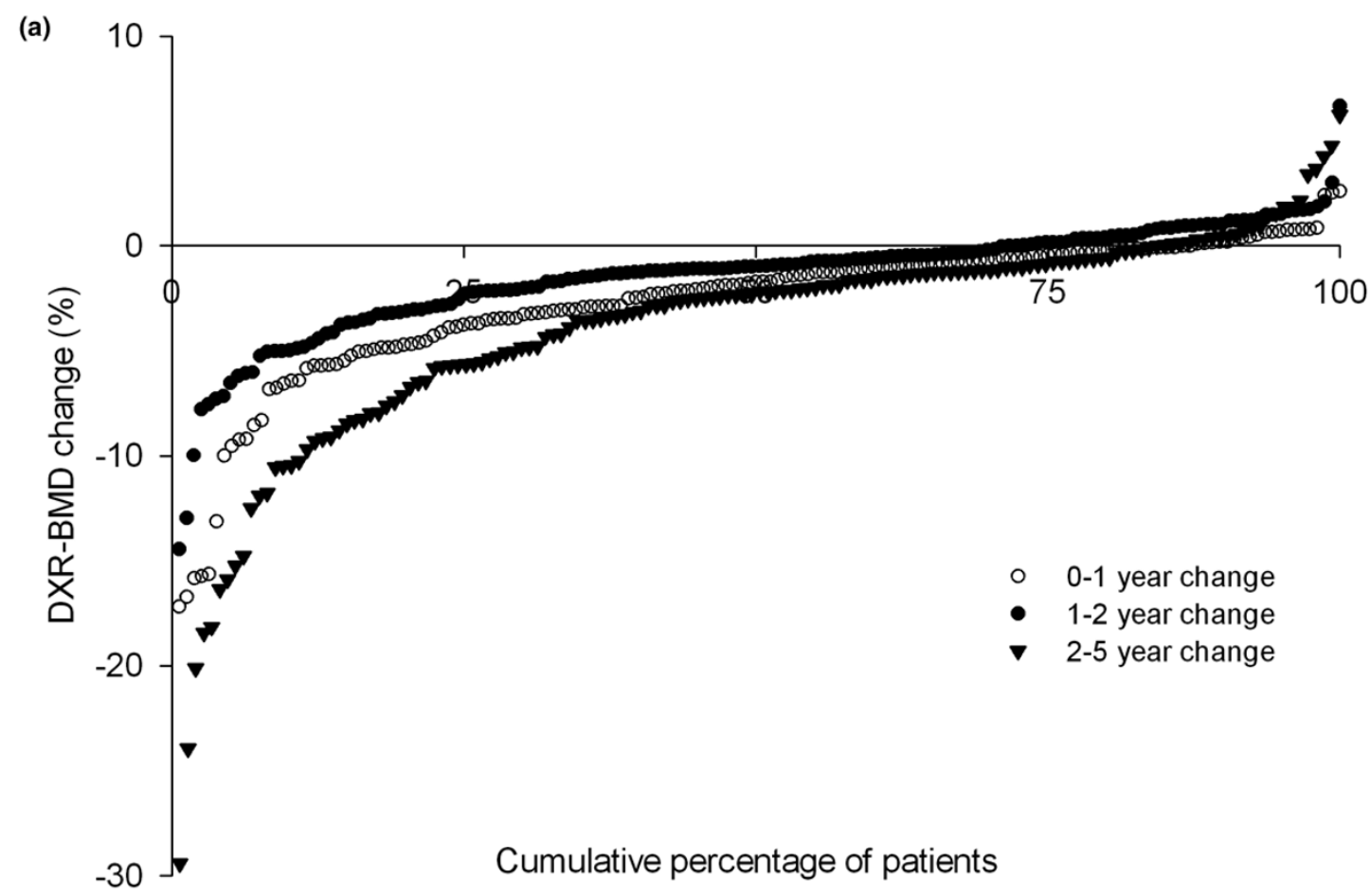

(b)

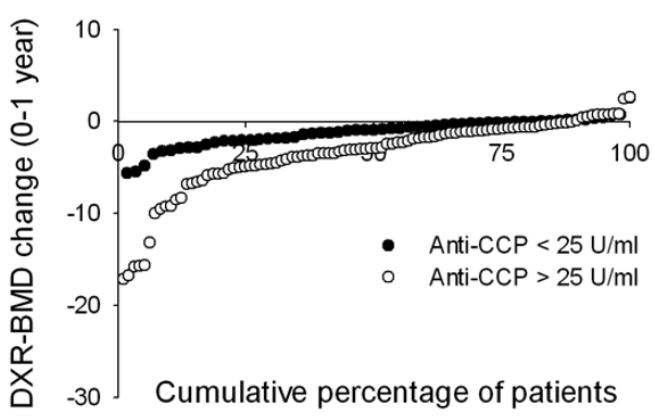

(c)

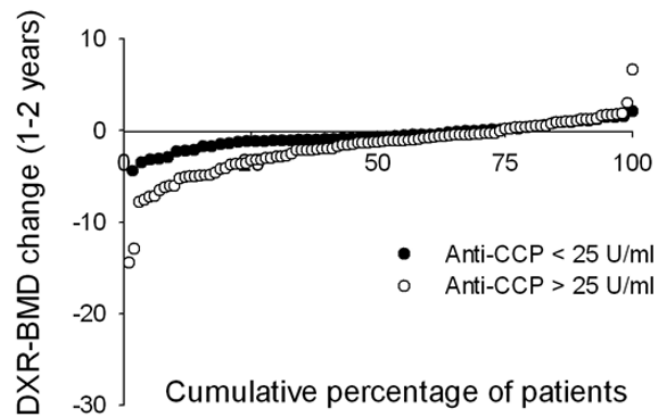

(d)

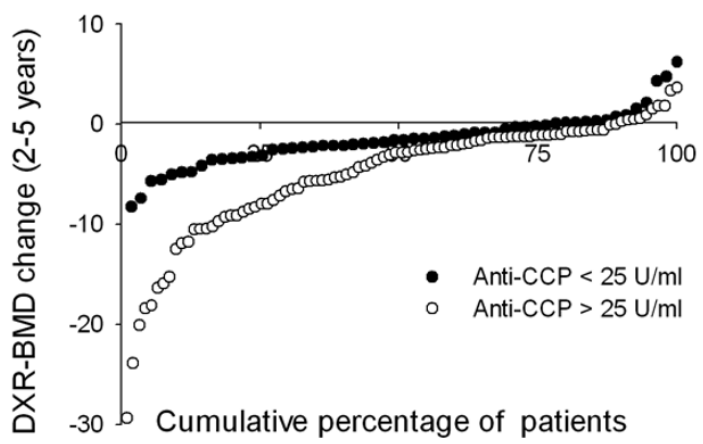

Cumulative probability plots presenting the individual patients' change in DXR-BMD. (a) Change in digital X-ray radiogrammetry bone mineral density (DXR-BMD) of the entire study group (0 to 1 years, 1 to 2 years, 2 to 5 years). (b-d) Change in DXR-BMD stratified according to antibody to cyclic citrullinated proteins (anti-CCP) positive/negative patients (empty circle: anti-CCP $>25 \mathrm{U} / \mathrm{ml}$, filled circle: anti-CCP $\leq 25 \mathrm{U} / \mathrm{ml}$ ) for 0 to 1,1 to 2 and 2 to 5 year change, respectively. 
Table 2

DXR-BMD measurements

\begin{tabular}{lcccc}
\hline & Baseline $(\mathrm{n}=163)$ & One-year follow-up $(\mathrm{n}=156)$ & Two-year follow-up $(\mathrm{n}=154)$ & Five-year follow-up $(\mathrm{n}=138)$ \\
\hline DXR-BMD $\left(\mathrm{g} / \mathrm{cm}^{2}\right)$ & 0.560 & 0.545 & 0.528 & 0.508 \\
& $(0.491$ to 0.608$)$ & $(0.470$ to 0.590$)$ & $(0.458$ to 0.586$)$ & $(0.427$ to 0.572$)$ \\
DXR-BMD change $(\%)+$ & -1.72 & -2.80 & -5.58 \\
& $(-4.07$ to -0.36$)$ & $(-5.29$ to -0.86$)$ & $(-11.72$ to -2.31$)$ \\
$\begin{array}{l}\text { Patients with loss in cortical } \\
\text { hand bone }(\%) \neq\end{array}$ & 66.7 & 77.3 & 89.1 \\
\hline
\end{tabular}

Median (inter quartile range) for continuous variables, percentage for counts. Number of patients presented in brackets. $D X R-B M D=$ digital $X$-ray radiogrammetry bone mineral density. + DXR-BMD change from baseline ₹ Decrease in DXR-BMD exceeding the least significant change (least significant change $=-0.79 \%$ ).

patients at one, two and five-year follow-up, respectively (Table 2).

\section{Associations between baseline serological biomarkers and change in DXR-BMD}

A trend towards larger loss in DXR-BMD in RA patients with elevated levels of anti-CCP compared with patients with low levels was observed in cumulative probability plots (Figure $1 \mathrm{~b}$ to $1 \mathrm{~d})$. Similar trends were seen elevated vs. low levels of ESR, CRP and RF (data not shown).

Possible associations between DXR-BMD and the serological biomarkers were explored in linear regression analyses with DXR-BMD loss as the dependent variable. Elevated baseline

Table 3

\begin{tabular}{|c|c|c|c|c|c|c|}
\hline & \multicolumn{2}{|c|}{ One-year change in DXR-BMD (\%) } & \multicolumn{2}{|c|}{ Two-year change in DXR-BMD (\%) } & \multicolumn{2}{|c|}{ Five-year change in DXR-BMD (\%) } \\
\hline & $\begin{array}{c}\mathrm{B} \\
(95 \% \mathrm{Cl})\end{array}$ & $P$ value & $\begin{array}{c}\mathrm{B} \\
(95 \% \mathrm{Cl})\end{array}$ & $P$ value & $\begin{array}{c}\mathrm{B} \\
(95 \% \mathrm{Cl})\end{array}$ & $P$ value \\
\hline Age (years) & $\begin{array}{c}-0.1 \\
(-0.1 \text { to } 0.0)\end{array}$ & 0.03 & $\begin{array}{c}-0.1 \\
(-0.2 \text { to } 0.0)\end{array}$ & 0.002 & $\begin{array}{c}-0.2 \\
(-0.3 \text { to } 0.0)\end{array}$ & 0.004 \\
\hline Sex (female) & $\begin{array}{c}-0.1 \\
(-1.4 \text { to } 1.2)\end{array}$ & 0.90 & $\begin{array}{c}0.6 \\
(-1.3 \text { to } 2.4\end{array}$ & 0.54 & $\begin{array}{c}0.0 \\
(-3.0 \text { to } 3.1)\end{array}$ & 0.98 \\
\hline Disease duration (years) & $\begin{array}{c}0.1 \\
(-0.4 \text { to } 0.6)\end{array}$ & 0.74 & $\begin{array}{c}0.2 \\
(-0.5 \text { to } 0.9)\end{array}$ & 0.66 & $\begin{array}{c}0.8 \\
(-0.4 \text { to } 1.9)\end{array}$ & 0.18 \\
\hline $\mathrm{HAQ}$ & $\begin{array}{c}-1.4 \\
(-2.2 \text { to }-0.5)\end{array}$ & 0.003 & $\begin{array}{c}-1.9 \\
(-3.1 \text { to }-0.7)\end{array}$ & 0.003 & $\begin{array}{c}-2.3 \\
(-4.5 \text { to }-0.2)\end{array}$ & 0.03 \\
\hline $\mathrm{ESR}(>20 \mathrm{~mm} / \mathrm{h})$ & $\begin{array}{c}-2.9 \\
(-4.0 \text { to }-1.9)\end{array}$ & $<0.001$ & $\begin{array}{c}-4.2 \\
(-5.7 \text { to }-2.8)\end{array}$ & $<0.001$ & $\begin{array}{c}-6.6 \\
(-9.0 \text { to }-4.1)\end{array}$ & $>0.001$ \\
\hline $\mathrm{CRP}(>10 \mathrm{mg} / \mathrm{l})$ & $\begin{array}{c}-1.6 \\
(-2.8 \text { to }-0.3)\end{array}$ & 0.01 & $\begin{array}{c}-3.4 \\
(-5.1 \text { to }-1.7)\end{array}$ & $<0.001$ & $\begin{array}{c}-3.9 \\
(-6.8 \text { to }-1.0)\end{array}$ & 0.008 \\
\hline Anti-CCP $(>25 \mathrm{U} / \mathrm{ml})$ & $\begin{array}{c}-2.3 \\
(-3.4 \text { to }-1.2)\end{array}$ & $<0.001$ & $\begin{array}{c}-3.5 \\
(-5.1 \text { to }-2.0)\end{array}$ & $<0.001$ & $\begin{array}{c}-6.5 \\
(-9.0 \text { to }-4.0)\end{array}$ & $<0.001$ \\
\hline $\operatorname{lgA} \mathrm{RF}(>25 \mathrm{U} / \mathrm{ml})$ & $\begin{array}{c}-0.7 \\
(-1.9 \text { to } 0.5)\end{array}$ & 0.26 & $\begin{array}{c}-2.6 \\
(-4.3 \text { to }-1.0)\end{array}$ & 0.002 & $\begin{array}{c}-5.0 \\
(-7.6 \text { to }-2.3)\end{array}$ & $<0.001$ \\
\hline $\operatorname{lgM} \mathrm{RF}(>25 \mathrm{U} / \mathrm{ml})$ & $\begin{array}{c}-1.2 \\
(-2.3 \text { to }-0.1)\end{array}$ & 0.04 & $\begin{array}{c}-2.8 \\
(-4.4 \text { to }-1.3)\end{array}$ & $<0.001$ & $\begin{array}{c}-5.5 \\
(-8.0 \text { to }-3.0)\end{array}$ & $<0.001$ \\
\hline DMARD treatment & $\begin{array}{c}-1.6 \\
(-2.6 \text { to }-0.5)\end{array}$ & 0.003 & $\begin{array}{c}-2.6 \\
(-4.3 \text { to }-0.9)\end{array}$ & 0.004 & $\begin{array}{c}-5.0 \\
(-7.9 \text { to }-2.2)\end{array}$ & 0.001 \\
\hline Prednisolone use & $\begin{array}{c}-1.0 \\
(-2.2 \text { to } 0.1)\end{array}$ & 0.07 & $\begin{array}{c}-1.9 \\
(-3.5 \text { to }-0.4)\end{array}$ & 0.02 & $\begin{array}{c}-3.6 \\
(-6.2 \text { to }-1.0)\end{array}$ & 0.008 \\
\hline
\end{tabular}

Results from univariate linear regression analyses with DXR-BMD as dependent variable.

Anti-CCP = antibodies to cyclic citrullinated peptide; $\mathrm{Cl}=$ confidence interval; $\mathrm{CRP}=\mathrm{C}$-reactive protein; DMARD = disease-modifying antirheumatic drugs; DXR-BMD = hand bone mineral density estimated by digital X-ray radiogrammetry; ESR = erythrocyte sedimentation rate; $\mathrm{HAQ}=$ health assessment questionnaire; Ig = immunoglobulin; RA = rheumatoid arthritis; RF = rheumatoid arthritis. 
levels of anti-CCP, RF, ESR and CRP were associated with an increased one, two and five year DXR-BMD loss in univariate linear regression analyses (Table 3). Age, HAQ, and DMARD and prednisolone treatment were also associated with DXRBMD loss at all time points (Table 3 ).

In multivariate linear regression models, elevated levels of antiCCP and ESR were independently associated with one-year loss in DXR-BMD (Table 4). This finding was confirmed in multivariate regression models with two and five-year DXR-BMD change as a dependent variable. In addition, elevated baseline CRP levels and DMARD treatment were independently associated with two-year change in DXR-BMD, but not significantly associated with one and five-year change. Disease duration, $\mathrm{HAQ}$ and prednisolone use did not alter or influence any of the multivariate models.

\section{Predictors of cortical hand bone loss}

Possible predictors of cortical hand bone loss were also examined using univariate logistic regression models with loss in cortical hand bone exceeding LSC as the dependent variable. Elevated baseline levels of anti-CCP and ESR increased the odds of cortical hand bone loss at one, two and five-year follow-up in univariate logistic regression analyses (Table 5). Further, increased odds were observed in high levels of IgA RF for one and two years of bone loss and elevated lgM and CRP levels for two- and five-year bone loss. In addition, patients with increased age and $\mathrm{HAQ}$, and DMARD and prednisolone treatment had higher odds of bone loss.

Anti-CCP was a consistent and independent predictor of cortical hand bone loss during the five-year follow-up period in multivariate logistic regression analyses (Table 6). Elevated baseline ESR was independently predictive of one- and twoyear cortical hand bone loss. Two-year cortical hand bone loss was also predicted by prednisolone use.

\section{Discussion}

The main finding in this five-year longitudinal study of patients with RA of short disease duration was that cortical hand bone loss can be independently predicted by elevated levels of antiCCP and ESR. This finding adds to the understanding of antiCCP and ESR as important predictors of bone involvement in RA.

The bone involvement in RA has been shown to start in the inflamed synovium that express receptor activator of nuclear factor- $\kappa B$ ligand (RANKL), a cytokine known to mediate osteoclast differentiation and activation [1,2]. Expressed in increased amounts and up-regulated by cytokines such as IL1 and TNF $\alpha$, RANKL causes the osteoclast to outperform the osteoblast thus causing increased bone resorption and focal bone loss. This focal bone loss in RA is seen as a reduction in trabecular as well as cortical BMD [4,17-19]. In order to target therapy, prognostic factors of this focal damage should be

\section{Table 4}

\begin{tabular}{|c|c|c|c|c|c|c|}
\hline & \multicolumn{2}{|c|}{ One-year DXR-BMD change } & \multicolumn{2}{|c|}{ Two-year DXR-BMD change } & \multicolumn{2}{|c|}{ Five-year DXR-BMD change } \\
\hline & $\begin{array}{c}\mathrm{B} \\
(95 \% \mathrm{Cl})\end{array}$ & $P$ value & $\begin{array}{c}\mathrm{B} \\
(95 \% \mathrm{Cl})\end{array}$ & $P$ value & $\begin{array}{c}\mathrm{B} \\
(95 \% \mathrm{Cl})\end{array}$ & $P$ value \\
\hline Anti-CCP $(>25 \mathrm{U} / \mathrm{ml})$ & $\begin{array}{c}-1.7 \\
(-2.8 \text { to }-0.7)\end{array}$ & 0.002 & $\begin{array}{c}-2.1 \\
(-3.5 \text { to }-0.6)\end{array}$ & 0.006 & $\left(-7.8^{-5.5}\right.$ to -3.1$)$ & $<0.001$ \\
\hline $\mathrm{ESR}(>20 \mathrm{~mm} / \mathrm{h})$ & $\begin{array}{c}-2.5 \\
(-3.6 \text { to }-1.4)\end{array}$ & $<0.001$ & $\begin{array}{c}-3.2 \\
(-4.7 \text { to }-1.7)\end{array}$ & $<0.001$ & $\begin{array}{c}-5.2 \\
(-7.6 \text { to }-2.8)\end{array}$ & $<0.001$ \\
\hline $\mathrm{CRP}(>10 \mathrm{mg} / \mathrm{l})$ & & & $\begin{array}{c}-1.8 \\
(-3.4 \text { to }-0.3)\end{array}$ & 0.02 & & \\
\hline DMARD treatment & & & $\begin{array}{c}-1.4 \\
(-2.8 \text { to }-0.03)\end{array}$ & 0.05 & & \\
\hline Age (years) & $\begin{array}{c}-0.02 \\
(-0.07 \text { to } 0.02)\end{array}$ & 0.3 & $\begin{array}{c}-0.05 \\
(-0.1 \text { to } 0.002)\end{array}$ & 0.06 & $\begin{array}{c}-0.08 \\
(-0.2 \text { to } 0.01)\end{array}$ & 0.09 \\
\hline Sex (female) & $\begin{array}{c}0.3 \\
(-0.8 \text { to } 1.5)\end{array}$ & 0.6 & $\begin{array}{c}0.1 \\
(-0.3 \text { to } 2.8)\end{array}$ & 0.1 & $\begin{array}{c}0.5 \\
(-2.1 \text { to } 3.1)\end{array}$ & 0.5 \\
\hline Constant & $\begin{array}{c}0.5 \\
(-1.9 \text { to } 3.1)\end{array}$ & 0.7 & $\begin{array}{c}1.8 \\
(-1.5 \text { to } 5.1)\end{array}$ & 0.3 & $\begin{array}{c}1.8 \\
(-3.6 \text { to } 7.2)\end{array}$ & 0.5 \\
\hline Adjusted $\mathrm{R}^{2}$ & $21.1 \%$ & & $29.3 \%$ & & $28.5 \%$ & \\
\hline
\end{tabular}

Final models after multivariate linear regression analyses. Dependent variable: DXR-BMD change (\%). Anti-CCP = antibodies to cyclic citrullinated peptide; $\mathrm{Cl}=$ confidence interval; $\mathrm{CRP}=\mathrm{C}$-reactive protein; $\mathrm{DMARD}=$ disease-modifying antirheumatic drugs; DXR-BMD = hand bone mineral density estimated by digital X-ray radiogrammetry; ESR = erythrocyte sedimentation rate. 
Cortical hand bone loss and baseline serological biomarkers (univariate logistic regression analyses)

\begin{tabular}{|c|c|c|c|c|c|c|}
\hline & \multicolumn{2}{|c|}{ One-year cortical hand bone loss } & \multicolumn{2}{|c|}{ Two-year cortical hand bone loss } & \multicolumn{2}{|c|}{ Five-year cortical hand bone loss } \\
\hline & $\begin{array}{c}\text { OR } \\
(95 \% \mathrm{Cl})\end{array}$ & $P$ value & $\begin{array}{c}\text { OR } \\
(95 \% \mathrm{Cl})\end{array}$ & $P$ value & $\begin{array}{c}\text { OR } \\
(95 \% \mathrm{Cl})\end{array}$ & $P$ value \\
\hline Age (years) & $\begin{array}{c}1.0 \\
\text { (1.0 to } 1.0)\end{array}$ & 0.15 & $\begin{array}{c}1.0 \\
(1.0 \text { to } 1.1)\end{array}$ & 0.02 & $\begin{array}{c}1.1 \\
(1.0 \text { to } 1.1)\end{array}$ & 0.01 \\
\hline Sex (female) & $\begin{array}{c}1.3 \\
\text { (0.6 to } 2.7)\end{array}$ & 0.52 & $\begin{array}{c}2.0 \\
\text { (0.9 to } 4.5)\end{array}$ & 0.09 & $\begin{array}{c}1.0 \\
(0.3 \text { to } 3.5)\end{array}$ & 0.96 \\
\hline Disease duration (years) & $\begin{array}{c}1.0 \\
\text { (0.7 to } 1.3 \text { ) }\end{array}$ & 0.85 & $\begin{array}{c}1.1 \\
(0.8 \text { to } 1.5)\end{array}$ & 0.69 & $\begin{array}{c}1.1 \\
(0.7 \text { to } 1.7)\end{array}$ & 0.66 \\
\hline $\mathrm{HAQ}$ & $\begin{array}{c}1.9 \\
(1.1 \text { to } 3.4)\end{array}$ & 0.03 & $\begin{array}{c}2.5 \\
\text { (1.3 to } 5.0)\end{array}$ & 0.01 & $\begin{array}{c}1.5 \\
(0.6 \text { to } 3.7)\end{array}$ & 0.41 \\
\hline $\mathrm{ESR}(>20 \mathrm{~mm} / \mathrm{h})$ & $\begin{array}{c}5.2 \\
(2.4 \text { to } 11.1)\end{array}$ & $<0.001$ & $\begin{array}{c}5.5 \\
(2.2 \text { to } 13.7)\end{array}$ & $<0.001$ & $\begin{array}{c}4.6 \\
(1.2 \text { to } 17.0)\end{array}$ & 0.02 \\
\hline $\mathrm{CRP}(>10 \mathrm{mg} / \mathrm{l})$ & $\begin{array}{c}1.9 \\
\text { (0.9 to } 4.1)\end{array}$ & 0.11 & $\begin{array}{c}4.1 \\
(1.3 \text { to } 12.3)\end{array}$ & 0.01 & $\begin{array}{c}6.0 \\
(0.8 \text { to } 47.5)\end{array}$ & 0.09 \\
\hline Anti-CCP (> $25 \mathrm{U} / \mathrm{ml})$ & $\begin{array}{c}2.7 \\
(1.4 \text { to } 5.5)\end{array}$ & 0.004 & $\begin{array}{c}3.2 \\
(1.5 \text { to } 7.0)\end{array}$ & 0.003 & $\begin{array}{c}5.1 \\
(1.5 \text { to } 17.0)\end{array}$ & 0.01 \\
\hline $\lg A$ RF $(>25 \mathrm{U} / \mathrm{ml})$ & $\begin{array}{c}2.6 \\
\text { (1.2 to } 5.7)\end{array}$ & 0.01 & $\begin{array}{c}3.3 \\
(1.3 \text { to } 8.5)\end{array}$ & 0.01 & $\begin{array}{c}2.2 \\
(0.6 \text { to } 8.3)\end{array}$ & 0.23 \\
\hline $\operatorname{lgM} \mathrm{RF}(>25 \mathrm{U} / \mathrm{ml})$ & $\begin{array}{c}1.7 \\
\text { (0.8 to } 3.3)\end{array}$ & 0.14 & $\begin{array}{c}3.4 \\
\text { (1.5 to } 7.8)\end{array}$ & 0.005 & $\begin{array}{c}3.8 \\
\text { (1.0 to } 14.2)\end{array}$ & 0.05 \\
\hline DMARD use & $\begin{array}{c}2.1 \\
(1.0 \text { to } 4.3)\end{array}$ & 0.05 & $\begin{array}{c}2.9 \\
\text { (1.3 to } 6.3)\end{array}$ & 0.009 & $\begin{array}{c}2.5 \\
(0.8 \text { to } 7.4)\end{array}$ & 0.10 \\
\hline Prednisolone use & $\begin{array}{c}2.3 \\
(1.1 \text { to } 4.6)\end{array}$ & 0.02 & $\begin{array}{c}3.5 \\
\text { (1.5 to } 8.1)\end{array}$ & 0.004 & $\begin{array}{c}4.8 \\
\text { (1.2 to } 17.8)\end{array}$ & 0.02 \\
\hline
\end{tabular}

Results from univariate logistic regression analyses. Dependent variable: cortical hand bone loss exceeding the least significant change (least significant change $=-0.79 \%$ ).

Anti-CCP $=$ antibodies to cyclic citrullinated peptide; $\mathrm{Cl}=$ confidence interval; $\mathrm{CRP}=\mathrm{C}$-reactive protein; $\mathrm{DMARD}=$ disease-modifying antirheumatic drugs; $\mathrm{ESR}=$ erythrocyte sedimentation rate; $\mathrm{HAQ}=$ health assessment questionnaire; $\lg =$ immunoglobulin; $\mathrm{OR}=$ odds ratio; $\mathrm{RF}$ $=$ rheumatoid arthritis.

identified. Erosive disease seen in radiographs has across several studies been shown to be predicted by anti-CCP, RF, ESR and CRP [13]. Change in DXA-BMD hand has been found to be inversely correlated to CRP and RF $[18,20]$. CRP has also been found to be associated with one-year hand DXR-BMD change in the BeST study [21]. In this study we confirm that RF and CRP are associated with DXR-BMD. However, in addition we show that elevated levels of anti-CCP and ESR are independent predictors of DXR-BMD loss. These common predictors support that erosions and focal bone loss have a common cellular mechanism.

Use of corticosteroids in high dosages indisputably causes a wide range of adverse events, including corticosteroidinduced osteoporosis [22]. Results from studies investigating the effect of chronic low-dose glucocorticoid use on bone in RA are conflicting. Although some studies show increased BMD while using low-dose prednisolone, others show bone loss $[22,23]$. In this study the patients using prednisolone took a daily mean (standard deviation) dosage of 6.5 (2.7) $\mathrm{mg}$, they were older and had higher HAQ scores than those who did not (data not shown). With respect to DMARDs influence on BMD, Schorn and Mowat have demonstrated an increased cortical thickness in RA patients treated with penicillamine [24]. Kalla and colleagues have also shown that DMARD treatment increase the cortical bone mass in RA patients [25]. The DMARD-treated patients in this study had significantly higher anti-CCP levels than the patients not treated with DMARDs, indicating a more severe disease. We found that both DMARDs and prednisolone use was associated with DXRBMD loss. RA patients with severe disease are prone to experience bone loss due to inflammation and immobility, but they are also more likely to be treated with DMARDs or prednisolone. Therefore, confounding by indication might explain the associations between DMARD and prednisolone treatment and DXR-BMD loss [26]. We also found age and $\mathrm{HAQ}$ to be associated with increased bone loss. Increased age and impaired physical function has previously been shown to explain decreased BMD and might thereby interfere with the results [27]. 
Independent predictors of cortical hand bone loss, results from multivariate logistic regression analyses

\begin{tabular}{|c|c|c|c|c|c|c|}
\hline & \multicolumn{2}{|c|}{ One-year cortical hand bone loss } & \multicolumn{2}{|c|}{ Two-year cortical hand bone loss } & \multicolumn{2}{|c|}{ Five-year cortical hand bone loss } \\
\hline & $\begin{array}{c}\text { OR } \\
(95 \% \mathrm{Cl})\end{array}$ & $P$ value & $\begin{array}{c}\text { OR } \\
(95 \% \mathrm{Cl})\end{array}$ & $P$ value & $\begin{array}{c}\text { OR } \\
(95 \% \mathrm{Cl})\end{array}$ & $P$ value \\
\hline Anti-CCP (> $25 \mathrm{U} / \mathrm{ml})$ & $\begin{array}{c}2.2 \\
(1.0 \text { to } 4.5)\end{array}$ & 0.04 & $\begin{array}{c}2.6 \\
(1.1 \text { to } 6.2)\end{array}$ & 0.03 & $\begin{array}{c}4.9 \\
(1.4 \text { to } 16.7)\end{array}$ & 0.01 \\
\hline $\mathrm{ESR}(>20 \mathrm{~mm} / \mathrm{h})$ & $\begin{array}{c}4.5 \\
(2.0 \text { to } 9.9)\end{array}$ & $<0.001$ & $\begin{array}{c}3.5 \\
(1.3 \text { to } 9.3)\end{array}$ & 0.01 & & \\
\hline Prednisolone use & & & $\begin{array}{c}4.7 \\
\text { (1.6 to } 14.1)\end{array}$ & 0.006 & & \\
\hline Age (years) & $\begin{array}{c}1.0 \\
(0.9 \text { to } 1.0)\end{array}$ & 0.62 & $\begin{array}{c}1.0 \\
\text { (0.9 to } 1.1)\end{array}$ & 0.23 & $\begin{array}{c}1.1 \\
(1.0 \text { to } 1.1)\end{array}$ & 0.89 \\
\hline Sex (female) & $\begin{array}{c}1.0 \\
(0.4 \text { to } 2.4)\end{array}$ & 0.95 & $\begin{array}{c}0.5 \\
(0.2 \text { to } 1.3)\end{array}$ & 0.14 & $\begin{array}{c}0.9 \\
(0.2 \text { to } 3.4)\end{array}$ & 0.02 \\
\hline Constant & 0.5 & 0.35 & 0.4 & 0.37 & 0.3 & 0.31 \\
\hline
\end{tabular}

Final models after multivariate logistic regression analyses. Dependent variable: cortical hand bone loss (yes/no). Anti-CCP = antibodies to cyclic citrullinated peptide; $\mathrm{Cl}=$ confidence interval; ESR = erythrocyte sedimentation rate; $\mathrm{OR}=$ odds ratio.

A weakness of this study is a lack of available data on important factors that influence the BMD. There were no available data on use of vitamin $D$, calcium supplements, hormone replacement therapy or anti-resorptive treatment. Further, there were no available specifications on the different DMARDs used during the five-year period. The menopausal status of the patients was not known. The DXR-BMD loss was larger in women under 50 years than in those older than 50 years. This might be explained by a rapid bone loss in the immediate years following menopause. However, this finding was similar for men, suggesting that menopause did not influence these results. Another weakness of this study was that DXA-BMD measurements were not performed. The observed cortical bone loss could neither be validated against the measured gold standard DXA-BMD, nor could the observed predictors be validated against trabecular bone loss.

\section{Conclusions}

The results of these analyses imply that a hypothetical 40-yearold female RA patient with elevated levels of ESR and antiCCP would at one-year follow-up have a predicted DXR-BMD loss of $4.2 \%$ and an odds of 6.4 for cortical hand bone loss, compared with a similar patient with normal levels of ESR and anti-CCP (calculated from the multivariate regression models presented in Tables 4 and 6). Thus, our findings support that elevated levels of anti-CCP and ESR are important markers that have potential impact on the disease course and should have impact on considerations about treatment strategies in RA patients. Further, this observation adds support to the hypothesis of similar mechanisms being involved in hand bone loss and erosive disease.

\section{Competing interests}

The authors declare that they have no competing interests.

\section{Authors' contributions}

PB performed the statistical analyses and prepared the manuscript. $\mathrm{MH}$ contributed in the statistical analyses and substantially contributed to the manuscript. $S \varnothing$ organised the clinical data collection. GH organised the DXR-BMD data collection. SWS organised the data collection. PIG organised the immunoassays. CO organised the analyses of ESR and CRP. All the authors contributed to the manuscript. TKK conceived of the study, and participated in its design and coordination and substantially helped to draft the manuscript. All authors read and approved the final manuscript.

\section{Acknowledgements}

We thank Inge C. Olsen for guidance in the statistical analyses and Anders Strand for technical assistance.

\section{References}

1. Goldring SR: Pathogenesis of bone and cartilage destruction in rheumatoid arthritis. Rheumatology (Oxford) 2003, 42(Suppl 2):ii11-ii16.

2. Schett G, Hayer S, Zwerina J, Redlich K, Smolen JS: Mechanisms of Disease: the link between RANKL and arthritic bone disease. Nat Clin Pract Rheumatol 2005, 1:47-54.

3. Arnett FC, Edworthy SM, Bloch DA, McShane DJ, Fries JF, Cooper NS, Healey LA, Kaplan SR, Liang MH, Luthra HS: The American Rheumatism Association 1987 revised criteria for the classification of rheumatoid arthritis. Arthritis Rheum 1988, 31:315-324.

4. Hoff M, Haugeberg G, Kvien TK: Hand bone loss as an outcome measure in established rheumatoid arthritis: 2-year observational study comparing cortical and total bone loss. Arthritis Res Ther 2007, 9:R81.

5. Jørgensen JT, Andersen PB, Rosholm A, Bjarnason NH: Digital Xray radiogrammetry: a new appendicular bone densitometric method with high precision. Clin Physiol 2000, 20:330-335. 
6. Rosholm A, Hyldstrup L, Backsgaard L, Grunkin M, Thodberg HH: Estimation of bone mineral density by digital $\mathrm{X}$-ray radiogrammetry: theoretical background and clinical testing. Osteoporos Int 2001, 12:961-969.

7. Finckh $A$, Liang $M$, Van Herckenrode $C$, De Pablo P: Long-term impact of early treatment on radiographic progression in rheumatoid arthritis: A meta-analysis. Arthritis Rheum 2006, 55:864-872.

8. Quinn MA, Conaghan PG, Emery P: The therapeutic approach of early intervention for rheumatoid arthritis: what is the evidence?*. Rheumatology (Oxford) 2001, 40:1211-1220.

9. Syversen SW, Gaarder PI, Goll GL, Ødegård S, Haavardsholm EA, Mowinckel P, Heijde D van der, Landewe R, Kvien TK: High anti-cyclic citrullinated peptide levels and an algorithm of four variables predict radiographic progression in patients with rheumatoid arthritis: results from a 10-year longitudinal study. Ann Rheum Dis 2008, 67:212-217.

10. Heijde $D$ van der, van Leeuwen $M A$, van Riel $P L$, Koster $A M$, van't Hof MA, van Rijswijk MH, Putte LB van de: Biannual radiographic assessments of hands and feet in a three-year prospective followup of patients with early rheumatoid arthritis. Arthritis Rheum 1992, 35:26-34.

11. Jensen $T$, Klarlund $M$, Hansen $M$, Jensen $K E$, Pødenphant $J$, Hansen TM, Skjødt H, Hyldstrup L: Bone loss in unclassified polyarthritis and early rheumatoid arthritis is better detected by digital $x$ ray radiogrammetry than dual $x$ ray absorptiometry: relationship with disease activity and radiographic outcome. Ann Rheum Dis 2004, 63:15-22.

12. Hoff $M$, Haugeberg $G$, Ødegård $S$, Syversen $S$, Landewe $R$, van der HD, Kvien TK: Cortical hand bone loss after 1 year in early rheumatoid arthritis predicts radiographic hand joint damage at 5-year and 10-year follow-up. Ann Rheum Dis 2009, 68:324-329.

13. Morel J, Combe B: How to predict prognosis in early rheumatoid arthritis. Best Pract Res Clin Rheumatol 2005, 19:137-146.

14. Smedstad LM, Kvien TK, Moum T, Vaglum P: Life events, psychosocial factors, and demographic variables in early rheumatoid arthritis: relations to one-year changes in functional disability. $J$ Rheumatol 1995, 22:2218-2225.

15. Haugeberg G, Green MJ, Conaghan PG, Quinn M, Wakefield R, Proudman SM, Stewart S, Hensor E, Emery P: Hand bone densitometry: a more sensitive standard for the assessment of early bone damage in rheumatoid arthritis. Ann Rheum Dis 2007, 66:1513-1517.

16. Landewe R, Heijde D van der: Radiographic progression depicted by probability plots: presenting data with optimal use of individual values. Arthritis Rheum 2004, 50:699-706.

17. Sambrook PN, Ansell BM, Foster S, Gumpel JM, Hesp R, Reeve J: Bone turnover in early rheumatoid arthritis. 2. Longitudinal bone density studies. Ann Rheum Dis 1985, 44:580-584.

18. Deodhar AA, Brabyn J, Jones PW, Davis MJ, Woolf AD: Longitudinal study of hand bone densitometry in rheumatoid arthritis. Arthritis Rheum 1995, 38:1204-1210.

19. Stewart A, Mackenzie LM, Black AJ, Reid DM: Predicting erosive disease in rheumatoid arthritis. A longitudinal study of changes in bone density using digital $X$-ray radiogrammetry: a pilot study. Rheumatology (Oxford) 2004, 43:1561-1564.

20. Haugeberg G, Green MJ, Quinn MA, Marzo-Ortega H, Proudman S, Karim Z, Wakefield RJ, Conaghan PG, Stewart S, Emery P: Hand bone loss in early undifferentiated arthritis: evaluating bone mineral density loss before the development of rheumatoid arthritis. Ann Rheum Dis 2006, 65:736-740.

21. Güler-Yüksel M, Allaart CF, Goekoop-Ruiterman YP, de Vries-Bouwstra JK, van Groenendael JH, Mallee C, de Bois MH, Breedveld FC, Dijkmans BA, Lems WF: Changes in hand and generalised bone mineral density in patients with recent-onset rheumatoid arthritis. Ann Rheum Dis 2009, 68:330-336.

22. van Staa TP, Leufkens HG, Cooper C: The epidemiology of corticosteroid-induced osteoporosis: a meta-analysis. Osteoporos Int 2002, 13:777-787.

23. Da Silva JA, Jacobs JW, Kirwan JR, Boers M, Saag KG, Inês LB, de Koning EJ, Buttgereit F, Cutolo M, Capell H, Rau R, Bijlsma JW: Safety of low dose glucocorticoid treatment in rheumatoid arthritis: published evidence and prospective trial data. Ann Rheum Dis 2006, 65:285-293.
24. Schorn D, Mowat AG: Penicillamine in rheumatoid arthritis: wound healing, skin thickness and osteoporosis. Rheumatol Rehabil 1977, 16:223-230.

25. Kalla AA, Meyers OL, Chalton D, Heath S, Brown GM, Smith PR Burger MC: Increased metacarpal bone mass following 18 months of slow-acting antirheumatic drugs for rheumatoid arthritis. Br J Rheumatol 1991, 30:91-100.

26. Salas M: Confounding by indication: an example of variation in the use of epidemiologic terminology. Am J Epidemiol 1999, 149:981-983.

27. Gough AK, Lilley J, Eyre S, Holder RL, Emery P: Generalised bone loss in patients with early rheumatoid arthritis. Lancet 1994 344:23-27. 